Additional services for Geological Magazine:

\title{
Eo-Alpine metamorphism and the 'mid-Miocene thermal event' in the Western Carpathians (Slovakia): new evidence from multiple thermochronology
}

MARTIN DANIŠÍK, MILAN KOHÚT, NOREEN J. EVANS and BRAD J. MCDONALD

Geological Magazine / Volume 149 / Issue 01 / January 2012, pp 158 - 171

DOI: 10.1017/S0016756811000963, Published online: 11 November 2011

Link to this article: http://journals.cambridge.org/abstract_S0016756811000963

How to cite this article:

MARTIN DANIŠÍK, MILAN KOHÚT, NOREEN J. EVANS and BRAD J. MCDONALD (2012). Eo-Alpine metamorphism and the 'mid-Miocene thermal event' in the Western Carpathians (Slovakia): new evidence from multiple thermochronology. Geological Magazine, 149, pp 158-171 doi:10.1017/S0016756811000963

Request Permissions : $\underline{\text { Click here }}$ 


\title{
Eo-Alpine metamorphism and the 'mid-Miocene thermal event' in the Western Carpathians (Slovakia): new evidence from multiple thermochronology
}

\author{
MARTIN DANIŠÍK*扩, MILAN KOHÚT, NOREEN J. EVANS* \\ \&BRAD J. MCDONALD*q \\ *John de Laeter Centre for Isotope Research, Applied Geology, Curtin University of Technology, GPO Box U1987, \\ Perth WA 6845, Australia \\ $\ddagger$ Department of Earth and Ocean Sciences, The University of Waikato, Private Bag 3105, Hamilton 3240, New Zealand \\ §Dionýz Štúr State Institute of Geology, Mlynská dolina 1, 81704 Bratislava, Slovak Republic \\ ฯCSIRO Earth Science and Resource Engineering, ARRC, 26 Dick Perry Avenue, WA 6151, Australia
}

(Received 20 July 2011; accepted 27 September 2011)

\begin{abstract}
A combination of zircon $(\mathrm{U}-\mathrm{Th}) / \mathrm{He}(\mathrm{ZHe})$, apatite fission track (AFT) and apatite ( $\mathrm{U}-\mathrm{Th}) / \mathrm{He}(\mathrm{AHe})$ dating methods is applied to constrain the metamorphic and exhumation history of the Tatric part of the Branisko Mountains in the Western Carpathians. ZHe ages from the basement samples prove the basement experienced a very low-grade to low-grade Eo-Alpine metamorphic overprint in mid-Cretaceous times. Miocene AFT and AHe ages found in the basement and in the Palaeogene sediments conclusively demonstrate that the Branisko Mts experienced a 'mid-Miocene thermal event'. This thermal event had a regional character and was related to magmatic and/or burial heating that exposed the sediment and basement samples to $\sim 120-130{ }^{\circ} \mathrm{C}$ and $\sim 100-190{ }^{\circ} \mathrm{C}$, respectively.
\end{abstract}

Keywords: exhumation, zircon and apatite (U-Th)/He dating, apatite fission track dating, Branisko Mts, Western Carpathians

\section{Introduction}

The Western Carpathians in central Europe (Fig. 1a) represent the northernmost branch of the Alpine orogenic belt and form the westernmost segment of a curved Carpathian orogenic belt. Similar to other sectors of this belt, the Western Carpathians have experienced a rather complex Alpine tectonothermal history, comprising Jurassic rifting and basin formation, Cretaceous collisional tectonics, extensional collapse and lateral escape of fragments of the Adriatic (Apulian) plate and their intricate interaction with the European foreland in the Tertiary period (Royden, Horváth \& Burchfiel, 1982; Royden et al. 1983; Mahel', 1986; Ratschbacher et al. 1991a,b; Csontos, 1995; Plašienka et al. 1997; Tari et al. 1999; Frisch, Dunkl \& Kuhlemann, 2000; Wortel \& Spakman, 2000; Sperner, Ratschbacher \& Nemčok, 2002). The dynamics of the Western Carpathian orogen are, in general, well described by conceptual models

$\dagger$ Author for correspondence: m.danisik@waikato.ac.nz
(Ratschbacher et al. 1991a; Plašienka et al. 1997; Sperner, Ratschbacher \& Nemčok, 2002; Kováč et al. 1994, 2007). Owing to a lack of empirical data and the sparse geological record, however, a number of fundamental questions regarding the orogenesis (e.g. timing and grade of metamorphism, thermal histories of crystalline and sedimentary rocks, or the timing and nature of exhumation processes), remain open or controversial.

For instance, two competing opinions on the Alpine metamorphism dominate the literature. One traditional view is that Variscan crystalline basement complexes of the Tatric principal unit either completely lack or are only weakly overprinted by the Alpine metamorphism that is restricted only to shear zones, reaching $P-T$ conditions of the anchizone or lower greenschist facies (Krist et al. 1992; Madarás et al. 1996; Plašienka et al. 1997; Plašienka, 2003). The other opinion is that the Tatric crystalline complexes did experience a distinct very low-grade (anchizonal) Alpine metamorphic overprint (Faryad \& Dianiška, 2002; Danišík et al. 2008a, 2010, 2011). Likewise, there are two competing views on the timing and nature of exhumation in the Western Carpathians. Whereas Kováč et al. (1994) favour a progressive exhumation migrating from internal parts of the belt towards the orogenic front, and a simple cooling of crystalline complexes, Danišík et al. (2004, 2008a, 2010, 2011) argued for a complex thermal history with at least one phase of reheating related to Palaeogene sedimentary burial and/or Miocene mantle upwelling associated with volcanic activity and increased heat flow.

In an effort to evaluate and better distinguish between the contrasting models of Carpathian metamorphic and exhumation histories, we used a combination of three thermochronometers: zircon (U-Th)/He (ZHe), apatite fission track (AFT) and apatite (U-Th)/He (AHe), whose sensitivities cover the temperature range of $\sim 40-200{ }^{\circ} \mathrm{C}$ (Hurford, 1986; Wagner \& Van den haute, 1992; Wolf, Farley \& Kass, 1998; Carlson, Donelick \& Ketcham, 1999; Farley, 2000; Reiners et al. 2004). In addition to providing constraints on material paths at mid- to shallow crustal levels, allowing exhumation rate estimates over different portions of the thermal histories of the rocks, this temperature range can be an effective tool to detect very low-grade metamorphism, which is of particular importance here. 


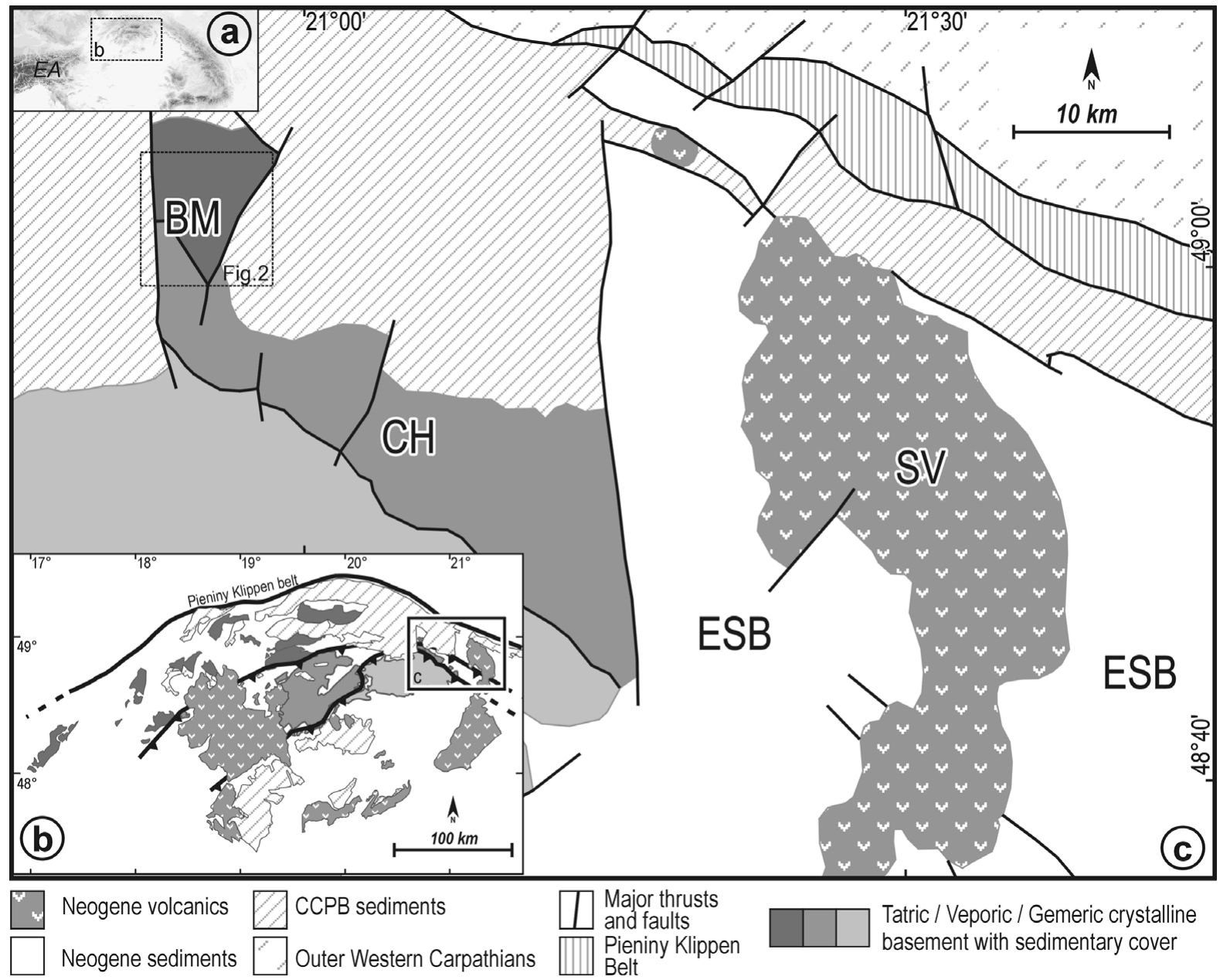

Figure 1. (a) The location of map (b) within the Alpine-Carpathian realm; EA - Eastern Alps. (b) Simplified geological map of the Western Carpathians with exposures of Variscan crystalline complexes (Tatric, Veporic and Gemeric superunits), occurrences of Palaeogene (CCPB) sedimentary and Neogene volcanic rocks, and location of the study area. (c) Geological map of the BM and surrounding areas (modified after Lexa et al. 2000). Abbreviations: BM - Branisko Mts, CH - Čierna Hora Mts, SV - Slánske Mts, ESB - Eastern Slovakian Basin.

In this study, we target the Branisko Mts (BM), a relatively small, but quite unique crystalline complex in the eastern part of the Western Carpathians (Fig. 1a, b). At least three aspects make the $\mathrm{BM}$ an interesting area to study the Carpathian orogenesis:

(i) The structure of the basement is fairly simple when compared to other massifs. While we acknowledge that some authors attributed the whole BM basement complex to the Veporic unit (Vozárová \& Vozár, 1986, 1988; Polák et al. 1997), we prefer the traditional classification (Rösing, 1947; Andrusov, 1958; Fusán, 1963; Mahel', 1986; Biely, 1996; Lexa et al. 2000; Plašienka, 2006) where two principal basement units are identified in the BM: the Tatric unit (or Tatricum) and the Veporic unit (Veporicum), which were juxtaposed during Alpine collision.

(ii) The Tatric part of the basement represents the easternmost outcrop of the Tatric unit in the Western Carpathians and no thermochronological data have been presented from this region yet.

(iii) Despite extensive research on the Variscan history (Rösing, 1947; Vozárová, 1993; Faryad, 1996; Jacko, 1998; Méres, Ivan \& Hovorka, 2000; Faryad, Ivan \& Jacko, 2005; Bónová \& Broska, 2006; Kohút et al. 2004, 2007, 2010), the Alpine tectonothermal evolution of the BM is virtually unconstrained.
Owing to the lack of thermochronological data, one can only speculate whether the BM escaped or experienced an Alpine metamorphic overprint (Plašienka et al. 1997; Faryad, 2002). It is also not clear whether the BM were exhumed in the Palaeogene as inferred from the analogy with other surrounding crystalline complexes (Kováč et al. 1994), or were buried and reheated by sediments of the Central Carpathian Palaeogene Basin (Danišík et al. 2004), and/or were reheated by the regional Miocene thermal event that was detected in several other crystalline massifs of the Western Carpathians (Danišík et al. 2004, 2008a,b, 2010, 2011). The new multi-thermochronological dataset presented in this study allows these hypotheses to be critically evaluated.

\section{Geological setting}

The focus of this study is largely on the northern, Tatric part of the BM (the so-called Smrekovica massif), which exhibits a typical Western Carpathian 'core mountain' structure (Fig. 2). It consists of a Variscan crystalline basement 'core' exposed in the central part of the massif and the Choč nappe comprising upper Carboniferous to upper Triassic formations preserved mostly along the northern margin of the BM. The Tatric part of the BM forms a N-trending, fault-bounded horst structure with elevations of $\sim 950 \mathrm{~m}$. To the west, north and east, it is flanked by the sediments of the Central 


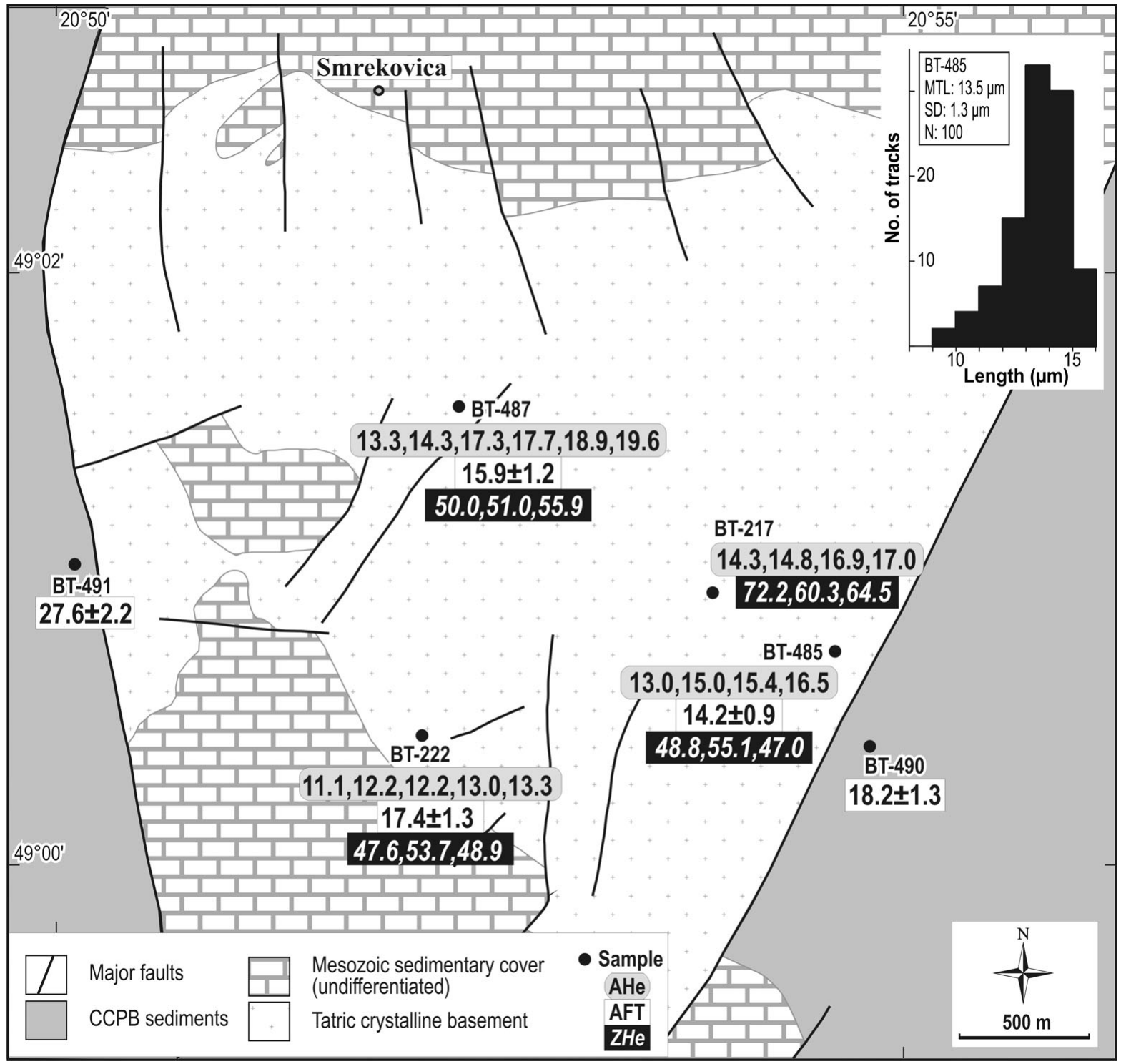

Figure 2. Thermochronological results (from top to bottom: sample code, single grain AHe ages measured on replicates, central AFT age with $1 \sigma$ error, single grain ZHe ages measured on replicates; all ages are quoted in Ma). Inset: track length distribution of sample BT-485. Abbreviations: MTL - mean track length \pm standard deviation (SD) in $\mu \mathrm{m} ; \mathrm{N}$ - number of measured tracks.

Carpathian Palaeogene Basin (CCPB); to the south, it is bordered by a Veporic basement unit (the so-called Sl'ubica massif). Although the contact of both basement units is not exposed, it is assumed that the Veporic basement is in the hanging-wall position separated from the Tatric part by the 'Harakovska' syncline and Kluknava thrust fault (Mahel', 1986).

The basement of the Tatric part consists of granitoids (including granite, granodiorite and tonalite) and medium- to high-grade metamorphic rocks, mostly gneisses, amphibolites and migmatites (Vozárová, 1993; Faryad, Ivan \& Jacko, 2005) ascribed to the Meso-Variscan metamorphic/magmatic event at $\sim 350 \mathrm{Ma}$ (monazite Th-U-Pb ages: $346 \pm 6 \mathrm{Ma}$ to $332 \pm 10 \mathrm{Ma}$; zircon rim U-Pb ages: $351 \pm 1.5 \mathrm{Ma}$; biotite Ar-Ar ages: $382 \pm 8$ Ma to $339 \pm 2 \mathrm{Ma}$; Kohút et al. 2004, 2007, 2010; Bónová et al. 2005). A systematic appearance of older ages $(\sim 475-455 \mathrm{Ma}$ and $\sim 420-390 \mathrm{Ma})$ revealed by zircon cores via SHRIMP as well as hornblende $\mathrm{Ar}-\mathrm{Ar}$ data may record the Ordovician protomagmatic age and a Silurian-Devonian tectonometamorphic event (Kohút et al. 2004, 2007, 2010). The post-Variscan sedimentary cover is represented by Permian arkoses, greywackes, conglomerates and sandy shales with thickness of up to 200-300 m and Scythian quartzites and variegated sericite schists reaching thicknesses of up to $\sim 120 \mathrm{~m}$ (Polák et al. 1997).

During the Eo-Alpine shortening in the period $\sim 110$ $85 \mathrm{Ma}$, the Tatric crystalline basement with its sediments was juxtaposed next to the Veporic basement and overthrust by the Choč nappe dominated by Triassic dolomites (Plašienka, 1997; Plašienka et al. 1997). The burial depth and possible Eo-Alpine metamorphism of the crystalline basement related to the thrusting is not precisely known. Faryad (2002), inferring from mineral assemblages in granite (replacement of plagioclase and biotite by white mica, epidote and chlorite), noted that the grade of Alpine metamorphism must have been lower than that observed in the adjacent Čierna Hora Mts, for which $P-T$ conditions of $250 \pm 25^{\circ} \mathrm{C}$ and $3 \mathrm{kbar}$ were reported on the basis of mineral assemblages (prehnite, pumpellyite, epidote, chlorite, albite and white mica; Faryad, Ivan \& Jacko, 2005; Korikovskij et al. 1992).

The post-tectonic evolution remains unclear because there are no post-tectonic sediments preserved directly on the horst of the BM. Clasts of Mesozoic carbonates present in the Middle Eocene basal sequence of the CCPB suggest that 
only the Mesozoic cover nappes were exposed to erosion prior to the Palaeogene transgression. No crystalline pebbles from the BM have been found in the CCPB suggesting that the crystalline basement remained buried.

The CCPB sediments surrounding the BM horst are represented mostly by deep marine flysch sediments of Bartonian to Eggenburgian age deposited by turbidity currents. At present, borehole and seismic data indicate that the CCPB column reaches a thickness of $\sim 3.5 \mathrm{~km}$ (e.g. seismic profile 753/92 (Hrušecký, Pospíšil \& Kohút, 2002); boreholes P1-1, Li-1, Li-2, S-1 (Gross, Köhler \& Samuel, 1984; Soták, 1998; Gross et al. 1999; Gross, 2008)). Fluid inclusion data indicate that an additional $\sim 6 \mathrm{~km}$ of CCPB sediments have been eroded (Hurai et al. 2000). Such an enormous thickness together with the lack of material derived from the $\mathrm{BM}$ in the $\mathrm{CCPB}$ sedimentary record suggests a complete burial of the massif to a depth of a few kilometres during Palaeogene times (Vass, Konečný \& Šefara, 1979; Kázmér et al. 2003), but the burial temperatures are not known. Inversion and disintegration of the CCPB basin occurred in latest Oligocene-early Miocene times as a result of NEE to NE compression (Nemčok, 1993) and is documented by gradual changes in the depositional environment (from deep marine to lagoonal), and by an angular unconformity between Egerian and Eggenburgian sediments (Rudinec, 1978, 1989; Vass \& Čverčko, 1985). There are no rocks of Ottnangian or younger age in the BM area, which points to an erosion event, but there is no evidence to indicate the timing of exhumation and erosion of the BM during this period.

The only geological record of the Neogene period is preserved $\sim 30 \mathrm{~km}$ east of the BM, and comprises sediments of the East Slovakian Basin (ESB) and volcanic rocks, constituting a prominent chain of andesitic stratovolcanoes called the Slánske Mts.

The ESB opened in a pull-apart regime in Karpatian time and, until Middle Badenian time, it was filled mostly by deep to shallow marine sediments (clays, sandstones, siltstones) reaching thickness of $\sim 3 \mathrm{~km}$ (Károli \& Zlínska, 1988; Zlínska, 1992; Kováć et al. 1995). The Upper BadenianLower Sarmatian depositional environment in the NW part of the basin is characterized by development of large deltas, indicating uplift and erosion of pre-Neogene rocks from the Western Carpathians (Vass \& Čverčko, 1985; Janočko, 1993; Kováč et al. 1995). In Late Sarmatian time, the basin was connected to, and became a part of the Pannonian basin system (Horváth, 1993) and the environment changed from brackish shallow marine to lagoonal and from freshwater deltaic to lacustrine (Kováč et al. 1995). The youngest deposits of Late Miocene-Pliocene age indicate inversion of the basin (Mořkovský \& Lukáčová, 1986, 1991).

The first pulses of volcanic activity in the ESB were related to subduction in front of the Western Carpathians and were documented by rhyolitic tuffs and small intrusions of Karpatian and Early Badenian age $(\sim 17 \mathrm{Ma}$ and $\sim 15.5$ 14.5 Ma; Slávik, 1968; Vass \& Čverčko, 1985; Lexa et al. 1993; Konečný et al. 2002). Subsequent volcanism of Late Badenian to Late Sarmatian age $(14.2-10.5 \mathrm{Ma})$ was, in contrast, related to extension and upwelling of asthenospheric mantle, producing rhyolitic extrusive domes and tuffs as well as andesite lava flows, intrusions and stratovolcanoes with diorite intrusions (Slávik et al. 1976; Vass et al. 1978; Kaličiak \& Repčok, 1987; Repčok, Kaličiak \& Bacsó, 1988; Lexa et al. 1993; Žec \& Durkovičová, 1993; Konečný et al. 2002).

The BM is dissected by NE-SW-, NW-SE- and N-Strending faults of Neogene age, whose origin can be related to the 'pull-apart' opening of the ESB (Kováč et al. 1995).

\section{Samples and methods}

Four crystalline basement samples previously used for U$\mathrm{Pb}$ geochronology (Kohút et al. 2004, 2007) were used for thermochronological investigations. In addition, two sandstone samples of the CCPB were collected from the western and eastern foothills of the range (for sample locations, coordinates and lithology see Fig. 2 and Table 1).

Zircon was dated by the (U-Th)/He method; apatite was dated both by fission track (FT) and (U-Th)/He methods. FT analysis was carried out using standard procedures described in Danišík et al. (2007). The external detector method (Gleadow, 1981) was applied with the etching protocol of Donelick, Ketcham \& Carlson (1999) (5.5 $\mathrm{M} \mathrm{HNO}_{3}$ for 20 seconds at $21^{\circ} \mathrm{C}$ ). The zeta calibration approach (Hurford \& Green, 1983) was adopted to determine the ages. FT ages were calculated using TrackKey 4.2g (Dunkl, 2002). Only one sample (BT-485) was suitable for measuring track lengths. In this sample, only horizontal confined tracks in tracks were measured in c-axis parallel surfaces and were normalized for crystallographic angle using a c-axis projection (Donelick, Ketcham \& Carlson, 1999; Ketcham et al. 2007a). The annealing properties of apatite were assessed by measuring the long axis of the track etch pits (Dpar; Burtner, Nigrini \& Donelick, 1994).

For $(\mathrm{U}-\mathrm{Th}) / \mathrm{He}$ analysis, apatite and zircon crystals were hand-picked following strict selection criteria (Farley, 2002; Reiners, 2005), then photographed and measured. Apatite was loaded in $\mathrm{Pt}$ tubes, degassed at $\sim 960{ }^{\circ} \mathrm{C}$ under vacuum using laser-heating and ${ }^{4} \mathrm{He}$ was measured using a Pfeiffer Prisma QMS-200 mass spectrometer. Following He measurements, the apatite was spiked with ${ }^{235} \mathrm{U}$ and ${ }^{230} \mathrm{Th}$, dissolved in nitric acid and analysed by isotope dilution inductively coupled mass spectrometry (ID ICP-MS) for U and Th on an Agilent 7500 ICP-MS. Zircon was loaded in Nb tubes, degassed at $\sim 1250{ }^{\circ} \mathrm{C}$ and analysed for ${ }^{4} \mathrm{He}$ using the same facility as for apatite. Degassed zircon was dissolved following the procedure of Evans et al. (2005) and analysed by ID ICP-MS for U and Th using the same facility as for apatite. For more details on analytical procedures, the reader is referred to Evans et al. (2005) and Danišík et al. (2008c).

The low-temperature thermal history based on FT and (U-Th)/He data was modelled using the HeFTy modelling program (Ketcham, 2005) operated with the multi-kinetic FT annealing model of Ketcham et al. (2007b) (using Dpar values as annealing kinetic parameter and initial track length estimated from Dpar) and the diffusion kinetics of the Durango apatite after Farley (2000) and zircon after Reiners et al. (2004).

\section{Results}

The results of thermochronological analyses are summarized in Tables 1 and 2 and shown in Figure 2. All dated samples yielded consistent results and the reproducibility of (U$\mathrm{Th}) / \mathrm{He}$ ages on replicates is excellent. ZHe ages are clearly older than AFT and AHe ages that record cooling of the samples through lower temperatures, which is in agreement with the closure temperature concept (Dodson, 1963).

\section{4.a. Basement samples}

Single grain $\mathrm{ZHe}$ ages of three out of the four basement samples form a tight cluster of Early-Middle Eocene age, ranging from $55.9 \pm 3.5 \mathrm{Ma}$ to $47.0 \pm 3.0 \mathrm{Ma}$ (9 replicates). Sample BTZ-217 revealed slightly older ZHe ages, loosely defining a Late Cretaceous-Paleocene age cluster (72.2 \pm $4.8 \mathrm{Ma}, 64.5 \pm 4.2 \mathrm{Ma}, 60.3 \pm 4.0 \mathrm{Ma})$. 


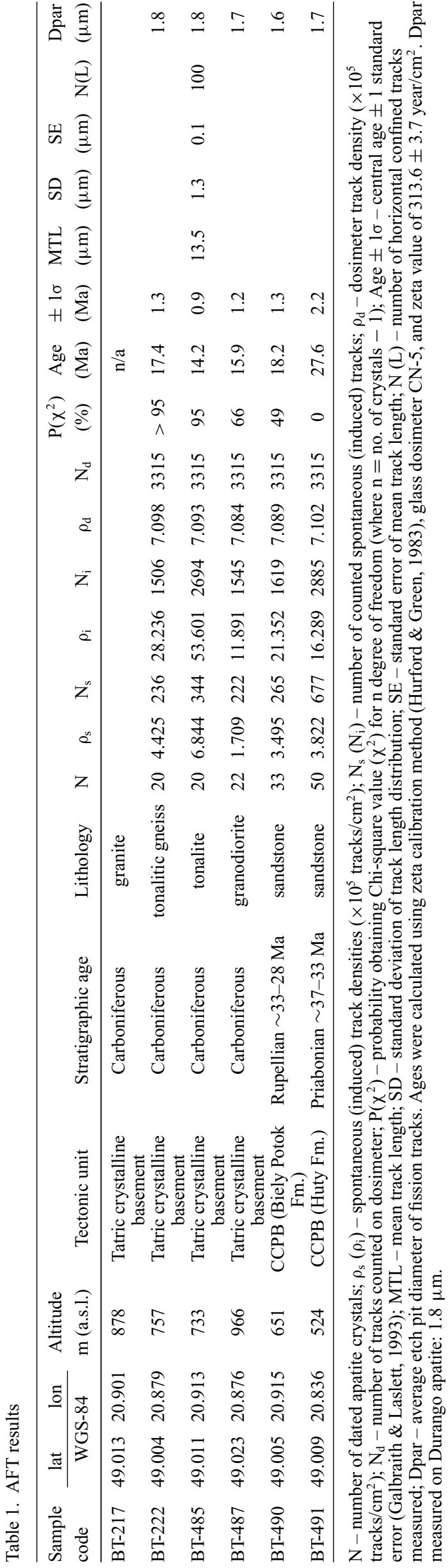

AFT and AHe results of all basement samples overlap within error and define one distinct cluster of late Earlyearly Late Miocene age: AFT and AHe ages range from $17.4 \pm 1.3 \mathrm{Ma}$ to $14.2 \pm 0.9 \mathrm{Ma}$ and from $19.6 \pm 1.3 \mathrm{Ma}$ to $11.1 \pm 0.7 \mathrm{Ma}$ (19 replicates). All AFT samples yielded narrow age spectra passing the chi-square test and are therefore considered to form one age population. The average Dpar value for all samples is $\sim 1.7 \mu \mathrm{m}$, indicating fluorinerich apatite, typified by a relatively low annealing temperature ( 60-120 ${ }^{\circ}$; ; e.g. Wagner \& Van den haute, 1992; Ketcham, Donelick \& Carlson, 1999). Track length distribution is unimodal and narrow with relatively short mean track length (MTL: $13.5 \mu \mathrm{m}$ ) (Fig. 2), which is typical for rocks with moderate cooling through the apatite partial annealing zone ( 60-120 ${ }^{\circ} \mathrm{C}$; Gleadow, Duddy \& Green, 1986a,b; Wagner \& Van den haute, 1992).

\section{4.b. CCPB samples}

Two samples (BT-490 and BT-491) from the Oligocene (Rupelian) and Eocene (Priabonian) sandstones of the CCPB yielded central AFT ages of $18.2 \pm 1.3 \mathrm{Ma}$ and $27.6 \pm$ 2.2 Ma, respectively (Fig. 3; Table 1). This clearly shows the samples have undergone a thermal overprint after deposition. The samples revealed broad single grain age spectra and failed the chi-square test, which shows that the samples consist of two or more age populations and that central AFT ages are not representative. In order to identify the individual age components we used the PopShare software (Dunkl \& Székely, 2003). Both samples contain a distinct Miocene age population $(15.9 \pm 4.3 \mathrm{Ma}$, and $11.0 \pm 1.9 \mathrm{Ma}$ or $18.0 \pm 7.4 \mathrm{Ma}$ ) but also some apatite grains of Palaeogene to Late Cretaceous AFT age that are clearly older than the depositional age (Fig. 3). These older grains, which are likely more resistant to annealing despite no deviation in the Dpar parameter, show the AFT thermochronometer was only partially reset after deposition, suggesting maximum temperatures below $\sim 130{ }^{\circ} \mathrm{C}$ (assuming a slightly higher temperature range of partial annealing zone for more resistant apatite; e.g. Carlson, Donelick \& Ketcham, 1999). Sample BT-490 east of the BM was reset to a higher degree than sample BT-491 to the west, as it contained a much higher proportion of fully reset grains than the latter $(\sim 87 \%$ versus $\sim 41 \%$, respectively).

\section{Interpretation and discussion}

\section{5.a. Alpine metamorphism}

The Late Cretaceous-Eocene ZHe ages show that the BM crystalline basement reached temperatures above $\sim 180{ }^{\circ} \mathrm{C}$ (closure temperature of the ZHe system; Reiners et al. 2004) during post-Variscan times as the ZHe system was fully reset. When only thermochronological data are considered, the maximum temperature is constrained to less than $\sim 310^{\circ} \mathrm{C}$ (the closure temperature of $\mathrm{Ar} / \mathrm{Ar}$ system in biotite; Harrison, Duncan \& McDougall, 1985; McDougall \& Harrison, 1988), since the biotite $\mathrm{Ar}-\mathrm{Ar}$ ages are Variscan $(382 \pm 8 \mathrm{Ma}$ to $339 \pm 2$ Ma; Kohút et al. 2004, 2007, 2010). Therefore, the Tatric crystalline complex must have experienced a very lowgrade or low-grade Alpine metamorphic overprint (assuming $300{ }^{\circ} \mathrm{C}$ as an arbitrary boundary between the two fields; Árkai, Sassi \& Desmons, 2002). This conclusion supports Faryad (2002) who noted similar mineral assemblages in the adjacent Čierna Hora Mts, and argued for $P-T$ conditions of less than $250 \pm 25^{\circ} \mathrm{C}$ and $3 \mathrm{kbar}$.

From the perspective of regional geology this is another strong argument against the traditionally accepted notion that there was no Alpine overprint in the Tatric superunit 


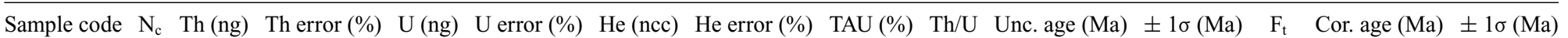

zircon

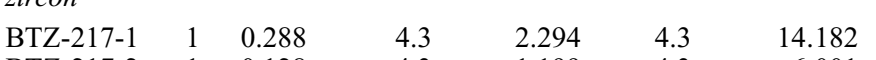

BTZ-217-2 $1-0.288$

$\begin{array}{lll}\text { BTZ-217-4 } & 1 & 0.173 \\ \text { Central age (Ma) } & 0.1 \text { Std. dev. (Ma) }\end{array}$

Central age (Ma) \pm Std. dev. (1

$\begin{array}{rrrr}2.294 & 4.3 & 14.182 & 0.5 \\ 1.199 & 4.3 & 6.001 & 0.5 \\ 1.437 & 4.2 & 7.963 & 0.5\end{array}$

\section{$\begin{array}{ll}4.3 & 0.12\end{array}$}

49.2

40.0

$\begin{array}{ll}2.1 & 0.68 \\ 1.7 & 0.66\end{array}$

$\begin{array}{ll}72.2 & 4.8 \\ 60.3 & 4.0\end{array}$

$64.5+6.5+6.1$

$\begin{array}{llll}\text { BTZ-222-1 } & 1 & 0.294 & 4.5 \\ \text { BTZ-222-2 } & 1 & 0.386 & 4.3\end{array}$

$\begin{array}{lccc}\text { BTZ-222-3 } & 1 & 0.270 & 4.3 \\ \text { Central age (Ma) } & \pm \text { Std. dev. (Ma) }\end{array}$

$\begin{array}{llll}3.304 & 4.3 & 14.117 & 0.5\end{array}$

$\begin{array}{lll}2.637 & 4.3 & 13.954\end{array}$

13.954
20.225

$\begin{array}{ll}4.3 & 0.09\end{array}$

$\begin{array}{llll}\text { BTZ-485-1 } & 1 & 2.072 & 4.0\end{array}$

$\begin{array}{llll}\text { BTZ-485-2 } & 1 & 1.967 & 4.0 \\ \text { BTZ-485-3 } & 1 & 0.671 & 4.0\end{array}$

26.412

$\begin{array}{lll}4.306 & 4.0 & 26.412 \\ 4.952 & 4.0 & 34.297 \\ 3.516 & 4.0 & 18.772\end{array}$

$3.516 \quad 4.0$

34.297
18.772

Central age (Ma) \pm Std. dev. (Ma)

$\begin{array}{llll}\text { BTZ-487-2 } & 1 & 2.020 & 3.9 \\ \text { BTZ-487-3 } & 1 & 0.320 & 4.0\end{array}$

$\begin{array}{llll}\text { BTZ-487-3 } & 1 & 0.320 & 4.0 \\ \text { BTZ-487-4 } & 1 & 1.493 & 4.0\end{array}$

$\begin{array}{lll}3.936 & 4.0 & 22.296\end{array}$

$\begin{array}{rrr}1.599 & 4.0 & 8.689\end{array}$

$7.504 \quad 4.1$

8.689
47.982

0.6
0.6
0.6

Central age (Ma) \pm Std. dev. (Ma)

apatite

$\begin{array}{llllll}\text { BTA-217-1 } & 1 & 0.146 & 3.7 & 0.341 & 3.9\end{array}$

$\begin{array}{lllllll}\text { BTA-217-1 } & 1 & 0.146 & 3.7 & 0.341 & 3.9 & 0.608\end{array}$

$\begin{array}{lllllll}\text { BTA-217-2 } & 1 & 0.100 & 3.8 & 0.222 & 3.9 & 0.391\end{array}$

$\begin{array}{lll}0.341 & 3.9 & 0.608 \\ 0.485 & 3.9 & 0.391\end{array}$

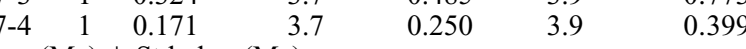

$0.773-0.5$

Central age (Ma) \pm Std. dev. (Ma)

$\begin{array}{llll}\text { BTA-222-1 } & 1 & 0.002 & 7.3 \\ \text { BTA-22-2 } & 1 & 0.003 & 5.4\end{array}$

$\begin{array}{llll}\text { BTA-222-4 } & 1 & 0.010 & 4.0 \\ \text { BTA-222-5 } & 1 & 0.017 & 3.8\end{array}$

$\begin{array}{llll}\text { BTA-222-6 } & 1 & 0.024 & 3.8\end{array}$

Central age (Ma) \pm Std. dev. (

$\begin{array}{llll}\text { BTA-485-1 } & 1 & 0.171 & 3.7 \\ \text { BTA-485-2 } & 1 & 0.114 & 3.7\end{array}$

$\begin{array}{llll}\text { BTA-485-3 } & 1 & 0.122 & 3.8 \\ \text { BTA-485-5 } & 1 & 0.105 & 3.8\end{array}$

Central age (Ma) \pm Std. dev. (Ma)

$\begin{array}{llll}\text { BTA-487-1x } & 1 & 0.005 & 5.9\end{array}$

$\begin{array}{llll}\text { BTA-487-2x } & 1 & 0.009 & 4.4\end{array}$

$\begin{array}{llll}\text { BTA-487-3x } & 1 & 0.005 & 5.1\end{array}$

$\begin{array}{llll}\text { BTA-487-3 } & 1 & 0.250 & 3.7\end{array}$

$\begin{array}{llll}\text { BTA-487-4 } & 1 & 0.178 & 3.7 \\ \text { BTA-487-5 } & 1 & 0.099 & 3.7\end{array}$

Central age (Ma) \pm Std. dev. (Ma)

$\begin{array}{ll}0.057 & 3.9 \\ 0.068 & 3.9 \\ 0.298 & 3.8 \\ 0.404 & 3.9 \\ 0.546 & 3.9 \\ & \\ 0.261 & 3.9 \\ 0.206 & 3.9 \\ 0.241 & 3.9 \\ 0.122 & 3.9 \\ & \\ 0.041 & 3 . \\ 0.044 & 3.9 \\ 0.065 & 3.9 \\ 0.269 & 3.9 \\ 0.269 & 3.9 \\ 0.150 & 3.9\end{array}$

0.054

0.076
0.385

0.385

0.683

0.391

0.307

0.389

0.210

0.064

0.096

0.096
0.127
0.412

0.412
0.546

0.546

$\mathrm{N}_{\mathrm{c}}$ - number of dated apatite crystals; Th $-{ }^{232} \mathrm{Th} ; \mathrm{U}-{ }^{238} \mathrm{U}$; He $-{ }^{4} \mathrm{He}$; TAU - total analytical uncertainty; Unc. age - uncorrected He age; $\mathrm{F}_{\mathrm{t}}-$ alpha recoil correction

$\begin{array}{ll}47.6 & 3.1 \\ 53.7 & 3.5\end{array}$

$\mathbf{5 0 . 0} \pm \mathbf{3 . 2}$

$\begin{array}{rr}48.8 & 3.0 \\ 5.1 & 3.4\end{array}$

$47.0 \quad 3.0$

$50.0 \quad 3.1$

$\begin{array}{lr}51.0 & 3.2 \\ 55.9 & 3.5\end{array}$

$\mathbf{5 2 . 2} \pm \mathbf{3 . 1}$

factor after Farley, Wolf \& Silver (1996) and Hourigan, Reiners \& Brandon (2005); Cor. age - corrected He age. 

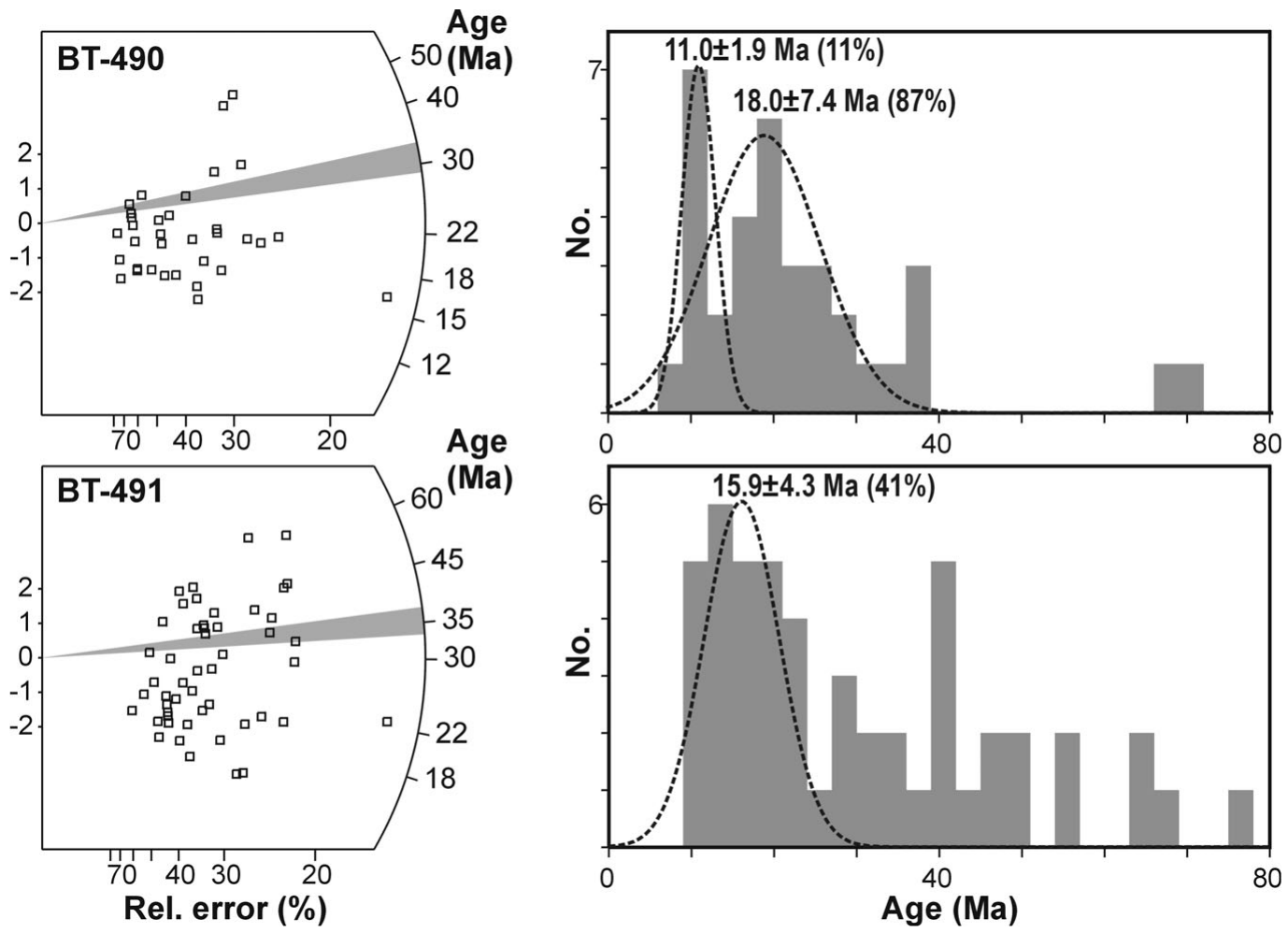

Figure 3. AFT data of two CCPB samples BT-490 and BT-491 (upper and lower panel, respectively) clearly documenting Miocene reheating: (left) radial plots (after Galbraith, 1988) with depositional age (grey); (right) histograms of single grain ages with the youngest age population of the samples identified by PopShare software (Dunkl \& Székely, 2003). Note that for sample BT-490 two alternative solutions $(11.0 \pm 1.9 \mathrm{Ma}$ or $18.0 \pm 7.4 \mathrm{Ma})$ without preference are proposed.

(Mahel', 1986; Plašienka et al. 1997; Plašienka, 2003). These data clearly support a very low-grade to low-grade Alpine overprint, as observed in other Tatric crystalline complexes (Faryad \& Dianiška, 2002; Faryad, Ivan \& Jacko, 2003; Danišík et al. 2008a, 2010, 2011).

Although the presence of Alpine metamorphism is univocally documented by the $\mathrm{ZHe}$ data, its timing and geodynamic context remains somewhat uncertain for the following two reasons. First, it is not entirely clear whether the $\mathrm{ZHe}$ ages are cooling ages corresponding to the age of a cooling event, or apparent ages resulting from some younger partial rejuvenation. Second, no distinct latest CretaceousEocene tectonothermal event has so far been reported from the Western Carpathians in traditional models.

We speculate about the following interpretations of the ZHe data:

The most plausible interpretation assumes that the $\mathrm{ZHe}$ ages are cooling ages recording a cooling of the basement through the ZHe partial retention zone $\left(\sim 160-200{ }^{\circ} \mathrm{C}\right.$; Reiners et al. 2004) during latest Cretaceous-Eocene times. The validity of this assumption may find support in good reproducibility and relatively low scatter of single grain ZHe ages (see Table 2), which is typical for quickly cooled samples (e.g. Fitzgerald et al. 2006). The latest CretaceousEocene ZHe ages are younger than the well-known Eo-Alpine collision in the Western Carpathians at $\sim 100-85 \mathrm{Ma}$, which is documented by stratigraphy, $\mathrm{Ar}-\mathrm{Ar}$ ages from shear zones and zircon FT data from crystalline rocks (Plašienka, 1997; Plašienka et al. 1997; Dallmeyer et al. 1996; Danišík et al. 2008a; Putiš et al. 2009). During the collision, the Tatric crystalline complexes were overthrust by superficial nappes. Their internal portion, including the BM, were perhaps partly overridden by the Veporic basement/cover complex, and reached the maximum pressure and temperature conditions. As explained above, the BM was buried to depths reflecting temperatures between $\sim 160$ and $\sim 250{ }^{\circ} \mathrm{C}$. The Eo-Alpine compression ceased after $\sim 80 \mathrm{Ma}$ and our ZHe ages likely record the cooling related to exhumation of the BM basement, pointing to an extensional collapse of the Carpathian orogenic wedge during latest Cretaceous-Eocene times.

Alternatively, since the distinct cluster of Early-Middle Eocene ZHe ages may appear too young to have the effect of straightforward cooling after the mid-Cretaceous thermal peak of Eo-Alpine metamorphism at $\sim 100-85 \mathrm{Ma}$, we acknowledge these ages could have been slightly rejuvenated by the Late Palaeogene burial thermal event and/or, more likely, by the Miocene thermal event discussed in the next Section. If this was the case, the ages would be apparent and the true timing of the post-metamorphic cooling as well as the post-orogenic collapse would have been older.

Almost identical Eocene ZHe and zircon FT track ages were reported from other Tatric crystalline complexes (e.g. in the Tribeč Mts, Malá Fatra Mts, Nízke Tatry Mts, Považský Inovec Mts and Malé Karpaty Mts; Kováč et al. 1994; Danišík et al. 2010, 2011) that should have a common or similar evolution to the BM throughout the Mesozoic and possibly also throughout the Tertiary. Danišík et al. (2010) provide extensive discussion on the possible meaning of these Eocene ages. In addition to the explanations presented above, Danišík et al. (2010) proposed an Eocene orogeny that perhaps might also extend to the BM. Notwithstanding this possibility and the plausibility of all interpretations, we prefer the first (i.e. the exhumation-related cooling following the mid-Cretaceous thermal peak) as the simplest explanation of the data.

\section{5.b. Mid-Miocene thermal event}

A tight cluster of late Early-early Late Miocene AFT and AHe ages from the basement samples (Fig. 2), distinct 


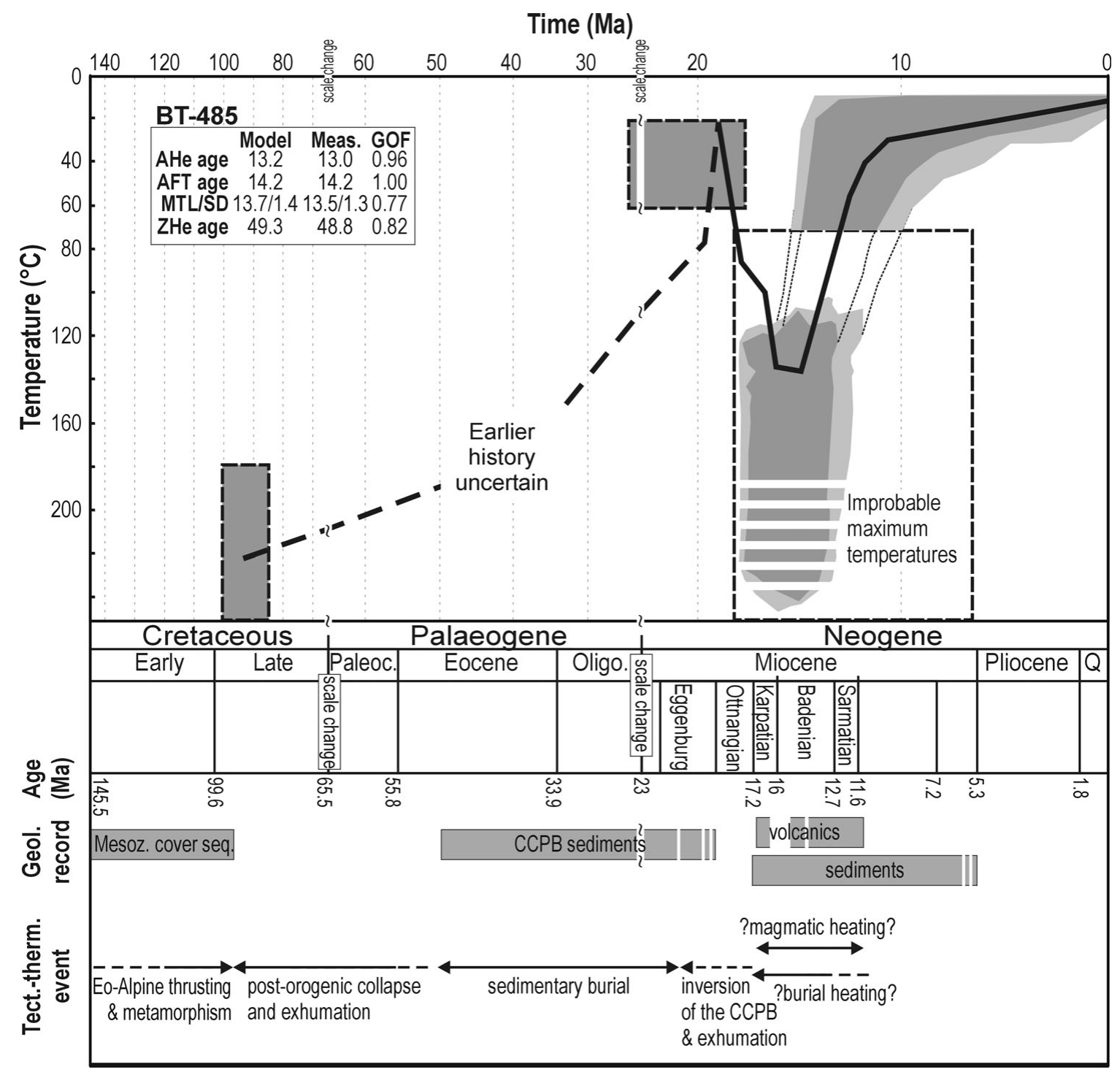

Figure 4. (Upper panel) Thermal modelling results of ZHe, AFT and AHe data displayed in a time-temperature diagram modelled with the HeFTy program (Ketcham, 2005). The best fit is shown as a black line, light and dark shaded polygons show acceptable and good fit, respectively; dashed rectangles are constraints discussed in the text. MTL - mean track length in $\mu \mathrm{m}$; SD - standard deviation in $\mu \mathrm{m}$; GOF - goodness of fit (statistical comparison of the measured input data and modelled output data, where a 'good' result corresponds to value 0.5 or higher; 'best' result corresponds to value 1 ). Note that this model aims to test timing and magnitude of the mid-Miocene thermal event recorded by a basement sample BT-485. According to the modelling results, between $\sim 18$ and 11 Ma the minimum and maximum temperatures must have exceeded $\sim 100^{\circ} \mathrm{C}$ and reached up to $\sim 240{ }^{\circ} \mathrm{C}$, respectively. However, maximum temperatures in the range of $190-240^{\circ} \mathrm{C}$ (hatched area) could have been reached only at extremely high, rather unrealistic cooling rates $\left(>50^{\circ} \mathrm{C} / \mathrm{Ma}\right)$ and are therefore less likely. Also note that this model provides little information on the thermal history prior to the Miocene thermal maximum. (Lower panel) Chronostratigraphic chart of the study area and surrounding regions with existing geological record and documented/presumed tectonothermal events (solid/dashed lines, respectively). Note the conspicuous overlap of the thermal maximum revealed by AFT data with contemporaneous volcanism and sedimentation in the area.

late Early and Middle Miocene age populations in the sedimentary samples and thermal modelling results (Fig. 4) offer strong evidence for a thermal event in about Middle Miocene time (hereafter termed the 'mid-Miocene thermal event'). However, given the lack of Neogene geological record in the study area, unravelling the meaning and the geodynamic context of this distinct event is not straightforward.

During this event, the Palaeogene sediment samples were heated to $\sim 120-130{ }^{\circ} \mathrm{C}$ (see Section 4.b) and experienced the post-depositional thermal maximum. Since the timing of the thermal peak overlaps with several geodynamic events in the area, we provide three alternative explanations:
First, the heating could have been related to burial by Neogene sediments. Despite the fact that at present there are no Neogene sedimentary formations preserved in the study area (only in the Košice depression further east) and that no palaeogeographic reconstructions account for this possibility (Kovác et al. 1995, 2007), at least three lines of evidence support the plausibility of Neogene burial. The first is the sedimentary record in the ESB, where up to $3000 \mathrm{~m}$ thick, deep to shallow marine sediments of Karpatian to Middle Badenian age occur, without traces of terrigenous sediment influx from a nearby landmass (Kováč et al. 1995). This suggests that the sea must have had a much larger extent at that time, likely blanketing a much larger area 


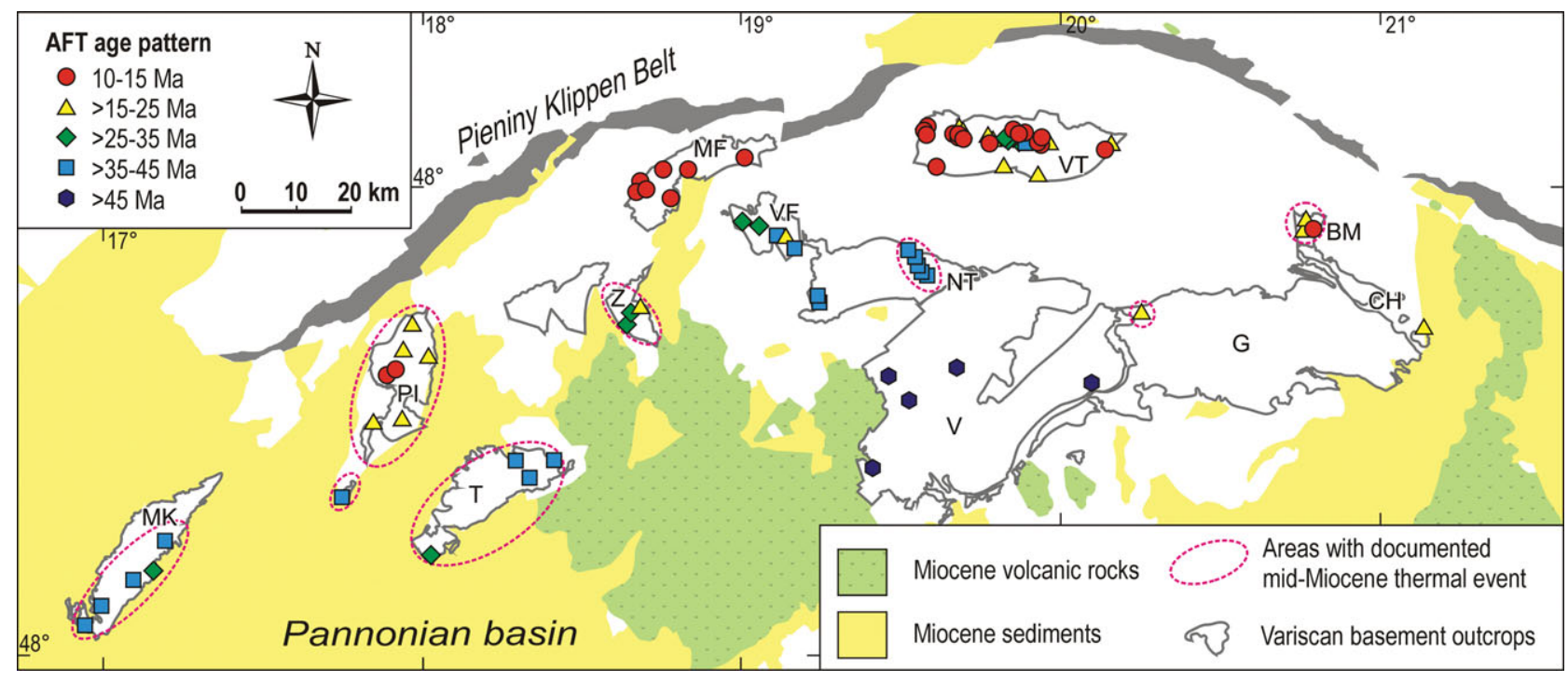

Figure 5. (Colour online) Simplified map of the Variscan crystalline outcrops (modified after Lexa et al. 2000) and existing AFT data, where a clear younging trend towards the former plate boundary (Pieniny Klippen Belt) is visible. Note that in several places with pre-Miocene AFT ages, a Miocene thermal event has been reported. We speculate that this regional event was related to the well-known magmatic activity in the Carpathian-Pannonian region manifested by Neogene volcanism (green) and/or to the burial by Neogene sediments belonging to the Pannonian basin that may have covered significant parts of the Western Carpathians, but due to later erosion were removed leaving only their remnants in isolated patches. AFT data are compiled from the following studies: Burchart (1972), Král' (1977), Kováč et al. (1994), Struzik, Zattin \& Anczkiewicz (2002), Baumgart-Kotarba \& Král' (2002), Danišík et al. (2004, 2008a,b, 2009, 2010, 2011). Abbreviations: BM - Branisko Mts, CH - Čierna Hora Mts, G - Gemeric superunit, MF - Malá Fatra Mts, MK - Malé Karpaty Mts, NT - Nízke Tatry Mts, PI - Považský Inovec Mts, T - Tribeč, V - Veporic superunit, VF - Vel’ká Fatra Mts, VT - Vysoké Tatry Mts, Z - Žiar Mts.

of the Western Carpathians, including the BM. Another argument is the spatial distribution of Miocene sediments in the Western Carpathians, which at present are preserved as isolated patches in intramontane depressions (Fig. 5). The similar character of the basin fill suggests that these isolated patches may have been interconnected or connected with the Pannonian basin system to the south of the Western Carpathians, indicating a much larger extent of Neogene cover. Lastly, Dunkl \& Frisch (2002) using AFT, vitrinite reflectance and seismic data showed that up to $1-1.5 \mathrm{~km}$ of Miocene sediments have been eroded from the northern margin of the Pannonian basin. This also supports a larger Pannonian basin in Miocene times and is thus consistent with the plausibility of the Miocene burial of the BM area.

Second, the heating could have been partly related to changes in the thermal regime. This interpretation finds support in the magmatic activity in the adjacent Slánske Mts, which occurred between $\sim 17$ and $11 \mathrm{Ma}$ (cf. Pécskay et al. 2006) and was related to subduction and mantle upwelling in the Carpathian-Pannonian region associated with high heat flow and an increased geothermal gradient (Král, Lisol \& Janáček, 1987; Szabó, Harangi \& Csontos, 1992; Tari, Horváth \& Rumpler, 1992). An extreme example of thermal regime reported from other parts of the Pannonian basin affected by volcanism (i.e. Styrian Basin) has shown that the Miocene heat flow could have reached as much as $\sim 250$ $\mathrm{mW} / \mathrm{m}^{2}$ (Sachsenhofer, 1994; Sachsenhofer et al. 1998). This value corresponds to the geothermal gradient of $\sim 80{ }^{\circ} \mathrm{C} / \mathrm{km}$ when the average thermal conductivity of $3.0 \mathrm{~W} / \mathrm{mK}$ for granite is assumed. If our samples resided at crustal depths of $2-2.5 \mathrm{~km}$ with a geothermal gradient of $\sim 25^{\circ} \mathrm{C} / \mathrm{km}$ prior to the mid-Miocene thermal maximum, a doubling of the geothermal gradient to a reasonable $\sim 50^{\circ} \mathrm{C} / \mathrm{km}$ in the study area during the thermal maximum could easily suffice to reach the desired $\sim 120-130{ }^{\circ} \mathrm{C}$.
Third, a combination of both mechanisms (i.e. magmatic heating and burial heating) appears to be the most likely scenario. The Miocene sequence in the ESB contains layers of fine-grained sediments with low thermal conductivity averaging $2 \mathrm{~W} / \mathrm{mK}$ (Dövényi \& Horváth, 1988; Král, 1994; Král \& Vitáloš, 2003). Even a relatively thin blanket of such sediments on the top of the BM area may have produced thermal isolation for underlying rocks and, in combination with an increased geothermal gradient induced by magmatism (Král, Lisol \& Janáček, 1987), could easily achieve the observed partial reset of the CCPB sediments.

The Eggenburgian-Ottnangian sedimentary record in the ESB may suggest exhumation and cooling of the BM in Early Miocene time. Considering this and the thermal history of the CCPB samples, one could postulate that during the mid-Miocene thermal event, the basement samples were heated from relatively colder conditions to their peak temperatures and were then brought back to the surface. In order to quantitatively constrain the maximum temperature of the basement during Miocene time, we used the HeFTy modelling program (Ketcham, 2005) to calculate thermal histories that reconcile the ZHe, AFT and AHe data. For the modelling (Fig. 4), we chose sample BT-485, for which $\mathrm{ZHe}, \mathrm{AFT}$ and AHe ages and FT lengths were measured (Tables 1,2). Available information was converted into timetemperature $(t-T)$ constraints in the form of boxes, through which the thermal histories are forced to pass, and the modelled $t-T$ path was constrained as follows: the beginning of the $t-T$ path was set as $T=\sim 180-250{ }^{\circ} \mathrm{C}$ at $\sim 100-85 \mathrm{Ma}$, according to the Eo-Alpine metamorphic peak temperatures discussed in Section 5.a. In Palaeogene time, the area was likely buried by flysch of the CCPB (Vass, Konečný \& Šefara, 1979; Kázmér et al. 2003). However, as we cannot draw any conclusion from our data as to the burial depth owing to the Miocene reset, no constraint for the Palaeogene was defined in the model. Since we assume that the basement resided 
at 'colder' conditions before reaching the Miocene thermal maximum (see Section 5.b), which fully reset the AHe and AFT systems, another constraint was set as $T=20-60^{\circ} \mathrm{C}$ at 24-18 Ma. The time component of this constraint was placed according to the time of CCPB inversion and the onset of volcanic activity and the Neogene sedimentation cycle, when the temperature minimum for the basement was most likely. For the rest of the Neogene we defined a broad temperature range $\left(T=60-200^{\circ} \mathrm{C}\right)$ in order to find all analytical solutions for the thermal peak. The end of the $t-T$ path was set as $T=10^{\circ} \mathrm{C}$ at $0 \mathrm{Ma}$ according to the annual mean surface temperature. We would like to emphasize that the aim of this model was to constrain the peak temperatures of the basement during the mid-Miocene thermal event and was not designed to unravel the Palaeogene burial history.

Results of the modelling (Fig. 4) suggest that the basement was heated to temperatures above $\sim 100{ }^{\circ} \mathrm{C}$ to up to $\sim 190{ }^{\circ} \mathrm{C}$ between $\sim 18$ and $11 \mathrm{Ma}$, and subsequent cooling to the near-surface conditions took place between $\sim 15$ and 9 Ma. Following the case of the CCPB samples, the thermal peak in the basement samples can be readily explained by magmatic and/or burial heating. The final cooling is most likely, although with some degree of uncertainty (see below), related to the exhumation of the basement. This interpretation may find indirect support in the Neogene sedimentary record in the ESB and also fits perfectly with the regional exhumation pattern of the crystalline basement complexes in the Western Carpathians (Danišík et al. 2010).

Neogene sediments in the ESB show shallowing of the depositional environment since Middle Badenian time. In Late Badenian-Early Sarmatian times, large southeastward prograding deltas developed (Kováč et al. 1995), indicating increased uplift and erosion of the catchment areas in the northwest that likely included the BM. Uplift and erosion continued until Late Miocene time when the environment gradually changed from deltaic to lacustrine (Kováč et al. 1995). It is very likely that the uplift and erosion resulting in exhumation is reflected in the modelled final cooling phase.

The Middle-Late Miocene exhumation of the BM is another valuable and well-fitting piece towards making the Western Carpathian exhumation puzzle complete. A clear younging of AFT ages towards the former plate boundary (Pieniny Klippen Belt) is evident in this picture (Fig. 5): internal massifs retain mostly Palaeogene or Cretaceous AFT ages and thus did not experience temperatures above $120^{\circ} \mathrm{C}$ during the Neogene. In contrast, all the external massifs, including the $\mathrm{BM}$, located closer to the plate boundary show almost exclusively Middle Miocene or younger AFT ages, which indicates their residence in a relatively 'hotter' environment (i.e. $>\sim 120^{\circ} \mathrm{C}$ ) in the Miocene prior to the final cooling.

Despite this seemingly unequivocal interpretation, it has to be noted that the Middle-Late Miocene exhumation of the BM is not directly corroborated by the geological record. And in fact it is not known when the basement was exposed to erosion. If the mid-Miocene thermal event was related solely to magmatic heating, it is entirely possible that the BM could have been exhumed and eroded already in Early Miocene time after inversion and disintegration of the CCPB. Therefore, it must be kept in mind that, if a mid-Miocene thermal event is detected in an area of the Western Carpathians and appropriate geological constraints are absent, interpretation of the thermal evolution prior to the thermal peak (including the Palaeogene history) remains ambiguous.

From a regional perspective, the existence of the midMiocene thermal event in the Western Carpathians has been documented in several crystalline bodies by AFT and AHe data (Fig. 5; Danišík et al. 2004, 2008a,b, 2010, 2011). Although its regional character is not in doubt, opinions regarding its cause are diverse. Danišík et al. (2004, 2008a,b, 2011), using the distribution of Neogene volcanism as an argument (Fig. 5), tended to attribute the thermal event primarily to the magmatic heating and associated high heat flow, whereas a Miocene sedimentary burial (favoured by Dunkl \& Frisch, 2002), would play a less important role. In this study, we are inclined to suggest that both burial and magmatic activity associated with high heat flow and sedimentary burial might have been equally responsible for the heating.

\section{Conclusions}

New ZHe, AFT and AHe data enabled us to constrain the tectonothermal evolution of the BM and provide important constraints on the thermal and geodynamic evolution of the Western Carpathians. The most important results are summarized as follows:

(i) The Variscan crystalline basement of the BM was heated to temperatures between $\sim 180$ and $250{ }^{\circ} \mathrm{C}$ and thus did experience a very low-grade to low-grade Alpine metamorphic overprint recorded by ZHe data;

(ii) Latest Cretaceous-Eocene ZHe ages are interpreted as cooling ages recording the exhumation of the BM basement related to the extensional collapse of the Carpathian orogenic wedge after the mid-Cretaceous (Eo-Alpine) collision and thrusting;

(iii) The basement and surrounding $\mathrm{CCPB}$ sediments experienced a mid-Miocene thermal event related to magmatic and/or burial heating. According to AFT, AHe and thermal modelling results, the CCPB sediments and the basement were heated to $\sim 120-130{ }^{\circ} \mathrm{C}$ and $\sim 110-190{ }^{\circ} \mathrm{C}$, respectively;

(iv) Final exhumation of the BM occurred in Early-Late Miocene times according to the thermal modelling. This conclusion is in good agreement with the sedimentary record in the adjacent ESB and fits well with the general exhumation pattern of crystalline bodies in the Western Carpathians with well-defined spatial AFT age patterns. The exhumation is, however, not directly corroborated by evidence from the geological record;

(v) Owing to the Miocene partial resetting of the CCPB samples, our data do not allow us to better constrain the CCPB burial history;

(vi) Detecting the mid-Miocene thermal event in the Western Carpathians by AFT and AHe systems proved to be a viable tool for reconstructing the original extent of Neogene sediments with application to palaeogeographic reconstructions.

Acknowledgements. We thank C. Scadding and A. Thomas for assistance with ICP-MS. MD received financial support from the WA Geothermal Centre of Excellence. MK was supported by the Slovak Research and Development Agency (No. APVV-549-07). An earlier version of the manuscript benefited from constructive reviews by Cristina Persano (Scotland) and an anonymous reviewer.

\section{References}

ANDrusov, D. 1958. Geológia Československých Kapát I, II. Bratislava: SAV, 304 pp.

Árkai, P., SAssi, F. P. \& DEsmons, J. 2002. Towards a unified nomenclature in metamorphic petrology: 4. Very low- to low-grade metamorphic rocks. A proposal on 
behalf of the IUGS Subcommission on the Systematics of Metamorphic Rocks. Web version of 31.10.2002: 12 pp., available online at http://www.bgs.ac.uk/SCMR.

BAUMGART-KotarbA, M. \& KRÁL', J. 2002. Young tectonic uplift of the Tatra Mts. (fission track data and geomorphological arguments). Proceedings of the XVII Congress of the Carpathian-Balkan Geological Association, Bratislava, Slovakia, September $1^{\text {st }}-4^{\text {th }}$, pp. 1-9; electronic supplement: http://www.geologicacarpathica. sk/special/B/Baumgart-Kotarba_Kotarba.pdf.

BIELY, A. 1996. Explanation to Geological Map of Slovakia. Bratislava: Dionýz Štúr Publishers, 76 pp.

BÓNOVÁ, K. \& BROSKA, I. 2006. Granitic rocks from Branisko Mts. (Western Carpathians): geochemistry, mineralogy and tectonic implications. Geolines 20, 20 1.

BÓNOVÁ, K., JACKO, S., BroskA, I. \& SimAN, P. 2005. Contribution to geochemistry and geochronology of leucogranites from Branisko Mts. Mineralia Slovaca 37, 349-50 (in Slovak).

BURCHART, J. 1972. Fission-track age determination of accessory apatite from the Tatra mountains, Poland. Earth and Planetary Science Letters 15, 418-22.

Burtner, R. L., Nigrini, A. \& Donelick, R. A. 1994. Thermochronology of Lower Cretaceous source rocks in the Idaho-Wyoming thrust belt. American Association of Petroleum Geologists Bulletin 78, 1613-36.

Carlson, W. D., Donelick, R. A. \& Ketcham, R. A. 1999. Variability of apatite fission-track annealing kinetics: I. Experimental results. American Mineralogist 84, 121323.

CsonTOS, L. 1995. Tertiary tectonic evolution of the IntraCarpathian area: a review. Acta Vulcanologica 7, 1-13.

DAllmeyer, R. D., NeUbauer, F., HANDler, R., Fritz, H., MÜller, W., PANA, D. \& PUTIŠ, M. 1996. Tectonothermal evolution of the internal Alps and Carpathians: evidence from ${ }^{40} \mathrm{Ar}{ }^{39} \mathrm{Ar}$ mineral and whole-rock data. Eclogae Geologicae Helvetiae 89, 203-27.

DANIŠÍK, M., DUNKL, I., PUTIŠ, M., FRISCH, W. \& KRÁL', J. 2004. Tertiary burial and exhumation history of basement highs along the NW margin of the Pannonian Basin - an apatite fission track study. Austrian Journal of Earth Sciences 95/96, 60-70.

DANišíK, M., KADlec, J., GlOTZBACH, CH., Weisheit, A., DunKL, I., KoHÚt, M., Evans, N. J., ORVošová, M. \& MCDONALD, B. J. 2011. Tracing metamorphism, exhumation and topographic evolution in orogenic belts by multiple thermochronology: a case study from the Nízke Tatry Mts., Western Carpathians. Swiss Journal of Geosciences 104, 285-98.

DANIŠíK, M., KoHÚT, M., BROSKA, I. \& FrISCH, W. 2010. Thermal evolution of the Malá Fatra Mountains (Central Western Carpathians): insights from zircon and apatite fission track thermochronology. Geologica Carpathica 61, 19-27.

DANIŠÍK, M., KoHÚT, M., DUNKL, I. \& FRISCH, W. $2008 a$. Thermal evolution of the Žiar Mountains basement (Inner Western Carpathians, Slovakia) constrained by fission track data. Geologica Carpathica 59, 19-30.

DANIŠÍK, M., KoHÚt, M., DUNKL, I. \& FrisCH, W. 2009. Fission track thremochronometry of the Vel'ká Fatra Mts. (Inner Western Carpathians, Slovakia): constraints on the Alpine tectonothermal evolution. $7^{\text {th }}$ Meeting of the Central European Tectonic Studies Group (CETeG), Hungary, $13^{\text {th }}-16^{\text {th }}$ May 2009, Abstracts.

DANiŠÍK, M., KoHÚT, M., DUNKL, I., HRAŠKO, L'. \& FRISCH, W. 2008b. Apatite fission track and (U$\mathrm{Th}) / \mathrm{He}$ thermochronology of the Rochovce granite
(Slovakia) - implications for thermal evolution of the Western Carpathians-Pannonian region. Swiss Journal of Geosciences 101, 225-33.

Danišík, M., Kuhlemann, J., Dunkl, I., SzÉKely, B. \& FRISCH, W. 2007. Burial and exhumation of Corsica (France) in the light of fission track data. Tectonics 26, TC1001, doi:10.1029/2005TC001938, 24 pp

Danišík, M., SaChSenhofer, R. F., Privalov, V. A., PANova, E. A., Frisch, W. \& SpIEgel, C. $2008 c$. Low-temperature thermal evolution of the Azov Massif (Ukrainian Shield - Ukraine) - implications for interpreting $(\mathrm{U}-\mathrm{Th}) / \mathrm{He}$ and fission track ages from cratons. Tectonophysics 456, 171-9.

Dodson, M. H. 1973. Closure temperatures in cooling geochronological and petrological systems. Contributions to Mineralogy and Petrology 40, 259-74.

Donelick, R. A., KeTCHAM, R. A. \& CARLSON, W. D. 1999. Variability of apatite fission-track annealing kinetics: I. Experimental results. American Mineralogist 84, 1224 34.

DÖVÉNYI, P. \& HoRVÁTH, F. 1988. A review of temperature, thermal conductivity, and heat flow data from the Pannonian Basin. In The Pannonian Basin. A study in basin evolution (eds L. H. Royden \& F. Horváth), pp. 195-233. American Association of Petroleum Geologists Memoir 45.

DUNKL, I. 2002. TRACKKEY: a Windows program for calculation and graphical presentation of fission track data. Computers and Geosciences 28, 3-12.

DUNKL, I. \& FRISCH, W. 2002. Thermochronologic constraints on the Late Cenozoic exhumation along the Alpine and West Carpathian margins of the Pannonian basin. In Neotectonics and Surface Processes: The Pannonian Basin and Alpine/Carpathian System (eds S. A. P. L. Cloething, F. Horváth, G. Bada \& A. C. Lankreijer), pp. 135-47. EGU Stephan Mueller Special Publication, Series 3.

DunKL, I. \& SzÉKELY, B. 2003. Component analysis with visualization of fitting - PopShare, a freeware program for evaluation of mixed geochronological data. Geophysical Research Abstracts 5, 02657.

Evans, N. J., Byrne, J. P., KeEgan, J. T. \& Dotter, L. E. 2005. Determination of uranium and thorium in zircon, apatite, and fluorite: application to laser (U-Th)/He thermochronology. Journal of Analytical Chemistry 60, 1159-65.

FARLEY, K. A. 2000. Helium diffusion from apatite: general behavior as illustrated by Durango fluorapatite. Journal of Geophysical Research 105(B2), 2903-14.

FARLEY, K. A. 2002. (U-Th)/He dating: techniques, calibrations, and applications. Reviews in Mineralogy and Geochemistry 47, 819-44.

FArley, K. A., Wolf, R. A. \& Silver, L. T. 1996. The effect of long alpha-stopping distances on (U-Th)/He ages. Geochimica et Cosmochimica Acta 60, 42239.

FARYAD, S. W. 1996. Petrology of amphibolites and gneisses from the Branisko crystalline complex. Mineralia Slovaca 28, 265-72.

FARYAD, S. W. 2002. Branisko \& Čierna Hora Mts - version 1. In Metamorphic Map and Database of CarpathoBalkan-Dinaride Area (eds I. Dunkl, I. Balintoni, W. Frisch, L. Hoxha, M. Janák, B. Koroknai, D. Milovanovic, J. Pamić, B. Székely \& M. Vrabec), http://www.met-map.uni-goettingen.de.

FARYAD, S. W. \& DIANIŠKA, I. 2002. Ti-bearing andradite-prehnite-epidote assemblage from the Malá Fatra granodiorite and tonalite (Western Carpathians). 
Schweizerische Mineralogische und Petrographische Mitteilungen 83, 47-56.

FARYAD, S. W., IVAN, P. \& JACKO, S. 2005. Metamorphic petrology of metabasites from the Branisko and Cierna Hora Mts. (Western Carpathians, Slovakia). Geologica Carpathica 56, 3-16.

FitzGerald, P. G., BALdwin, S. L., WebB, L. E. \& O'Sullivan, P. B. 2006. Interpretation of (U-Th)/He single grain ages from slowly cooled crustal terranes: a case study from the Transantarctic Mountains of southern Victoria Land. Chemical Geology 225, 91120.

Frisch, W., DunkL, I. \& KuhlemanN, J. 2000. Postcollisional largescale extension in the Eastern Alps. Tectonophysics 327, 239-65.

FusÁn, O. 1963. Explanations to the General Geological Map of ČSSR 1:200.000; Sheet M-34-XXVII Vysoké Tatry. Bratislava: Geofond, 215 pp. (in Slovak).

GALBRAITH, R. 1988. Graphical display of estimates having differing standard errors. Technometrics 30, 271-81.

Galbraith, R. F. \& LAslett, G. M. 1993. Statistical models for mixed fission track ages. Nuclear Tracks and Radiation Measurements 21, 459-70.

GLEADOW, A. J. W. 1981. Fission-track dating methods: what are the real alternatives? Nuclear Tracks and Radiation Measurements 5, 1/2, 3-14.

Gleadow, A. J. W., DudDY, I. R. \& GREen, P. F. $1986 a$. Fission track lengths in the apatite annealing zone and the interpretation of mixed ages. Earth and Planetary Science Letters 78, 245-54.

Gleadow, A. J. W., DudDY, I. R. \& GReEN, P. F. $1986 b$. Confined fission track lengths in apatite: a diagnostic tool for thermal history analysis. Contributions to Mineralogy and Petrology 94, 405-15.

GRoss, P. 2008. Lithostratigraphy of Western Carpathians: Paleogene - Podtatranská Group. Bratislava: Dionýz Štúr Publishing House, 78 pp. (in Slovak with English summary).

Gross, P., Buček, S., Ďurkovič, T., Filo, I., Maglay, J., HalouzKa, R., Karoli, S., NAGY, A., SPIŠIAK, Z., ŽEC, B., VOZÁR, J., BORZA, V., LUKÁČIK, E., MELlo, J., POLÁK, M. \& JANOČKO, J. 1999. Geological Map of the Poprad and Hornád Lowlands, Levoča hills, Spiš-Šariš Intermontane, Bachurña and Šariš Highlands 1:50.000. Bratislava: Dionýz Stúr Publishing House.

Gross, P., KÖHLER, E. \& SAMUEL, O. 1984. New lithostratigraphic classification of the Central Carpathians Paleogene. Geologické Práce, Správy 81, 103-17 (in Slovak).

HARRISON, T. M., DunCAN, I. \& MCDOUgall, I. 1985. Diffusion of ${ }^{40} \mathrm{Ar}$ in biotite: temperature, pressure and compositional effects. Geochimica et Cosmochimica Acta 49, 2461-8.

Horváth, F. 1993. Towards a mechanical model for the formation of the Pannonian Basin. Tectonophysics 226, 333-57.

Hourigan, J. K., Reiners, P. W. \& Brandon, M. T. 2005. U-Th zonation-dependent alpha-ejection in (U-Th)/He chronometry. Geochimica et Cosmochimica Acta 69, 3349-65.

HRUŠECKÝ, I., PosPíšIL, L. \& KoHÚT, M. 2002. Geological interpretation of the reflection seismic profile 753/92. In Hydrocarbon Potential of the Eastern Slovakian Basin and Adjacent Areas (ed. I. Hrušecký), pp. 1-47. Open File Report, Geofond, Bratislava, (in Slovak).

Hurai, V., ŚwierczewsKa, A., Marko, F., ToKarski, A. \& HRUŠECKÝ, I. 2000. Paleofluid temperatures and pressures in Tertiary accretionary prism of the Western Carpathians. Slovak Geological Magazine 6, 194-7.
Hurford, A. J. 1986. Cooling and uplift patterns in the Lepontine Alps South Central Switzerland and age of vertical movement on the Insubric fault line. Contributions to Mineralogy and Petrology 92, 413-27.

HURFORD, A. J. \& GREEN, P. F. 1983. The zeta age calibration of fission-track dating. Chemical Geology 41, 285-312.

JACKO, S. 1998. Tectonometamorphic evolution of the Branisko and Čierna hora Mts. Slovak Geological Magazine 4, 137-42.

JANOČKO, J. 1993. Development of a braided delta depositional system - Lower Sarmatian, Neogene East Slovakian Basin. In Sedimentological and Paleogeographical Analysis of the East Slovakian Basin (ed. D. Vass), pp. 1-16. Open File Report, Geofond Bratislava.

KALIČIAK, M. \& REPČOK, I. 1987. Reconstruction of evolution of volcanoes in the northern part of Slanské mountain range. Mineralia Slovaca 19, 401-15 (in Slovak).

KÁROLI, S. \& ZLÍNSKA, A. 1988. Results of the Lithological and Microbiostratigraphical Research of the Neogene of the Košice Depression. Open File Report, Geofond, Bratislava, 33 pp. (in Slovak).

KÁzmér, M., DunKL, I., Frisch, W., KuhlemanN, J. \& OZSVÁRT, P. 2003. The Palaeogene forearc basin of the Eastern Alps and the Western Carpathians: subduction erosion and basin evolution. Journal of the Geological Society, London 160, 413-28.

Ketcham, R. A. 2005. Forward and inverse modeling of low-temperature thermochronometry data. In LowTemperature Thermochronology: Techniques, Interpretations, and Applications (eds P. W. Reiners \& T. A. Ehlers), pp. 275-314. Reviews in Mineralogy and Geochemistry vol. 58.

Ketcham, R. A., Donelick, R. A. \& CARlson, W. D. 1999. Variability of apatite fission track annealing kinetics: III. Extrapolation to geologic time scales. American Mineralogist 84, 1235-55.

Ketcham, R. A., CARTer, A., Donelick, R. A., BARBARAND, J. \& HURFORD, A. J. 2007a. Improved measurement of fission-track annealing in apatite using c-axis projection. American Mineralogist 92, 789-98.

Ketcham, R. A., CARTER, A., DONElick, R. A., BARBARAND, J. \& HURFORD, A. J. 2007b. Improved modeling of fission-track annealing in apatite. American Mineralogist 92, 799-810.

Kohút, M., MÄnttäri, I., Sergeev, S., Putiš, M. \& UHER, P. 2007. SHRIMP zircon U-Pb dating of tonalitic gneisses from the Branisko Mts. Mineralia Slovaca 39, Geovestník, 6.

Kohút, M., Sherlock, S. C., Poller, U., KoneČnÝ, P., Siman, P. \& HolickÝ, I. 2004. The indications of the Pre-Hercynian and Hercynian evolution in the Patria crystalline complex - the Branisko Mts. (Western Carpathians, Slovakia). Environmental, Structural and Stratigraphical Evolution of the Western Carpathians (ESSE WECA) Conference 2004, Electronic Abstracts, pp. 1-4.

Kohút, M., Uher, P., Putiš, M., Broska, I., Siman, P., RoDionov, N. \& SERGEEV, S. 2010. Are there any differences in age of the two principal Hercynian (I\& S-) granite types from the Western Carpathians? - A SHRIMP approach. In Dating of Minerals and Rocks, Metamorphic, Magmatic and Metallogenetic Processes, As Well As Tectonic Events (ed. M. Kohút), pp. 17-8. Bratislava: Conferences, Symposia \& Seminars ŠGÚDŠ.

KoneČnÝ, V., KovÁČ, M., LeXA, J. \& Šefara, J. 2002. Neogene Evolution of the Carpatho-Pannonian Region: 
An interplay of subduction and back-arc diapiric uprise in the mantle. EGU Stephan Mueller Special Publication, Series 1, pp. 105-23.

KorikOVSKIJ, S. P., JACKO, S., BORONICHIN, A. A. \& ŠUCHA, V. 1992. Ilitte-paragonite layer intergrowths from the Gemericum nappe in the SE part of the Cierna Hora Mts. Veporicum (Western Carpathians). Geologica Carpathica 43, 49-55.

KovÁČ, M., ANDERYEVA-GRIGOROVICH, A., BaJtrakteravić, Z., BrZOBOHATÝ, R., Filipescu, S., Fodor, L., Harzhauser, M., Nagymarosy, A., OszczypKo, N., PAVelić, D., Rögl, F., SAFtić, B., SLIVA, L. \& STUDENCKA, B. 2007. Badenian evolution of the Central Paratethys sea: paleogeography, climate and eustatic sea level changes. Geologica Carpathica 58, 579-606.

KovÁč, M., KovÁč, P., MARKO, F., KAROLI, S. \& JANOČKO, J. 1995. The East Slovakian Basin - a complex back-arc basin. Tectonophysics 252, 453-66.

KovÁč, M., KrÁL', J., MÁrton, E., PlaŠIENKA, D. \& UHER, P. 1994. Alpine uplift history of the Central Western Carpathians: geochronological, paleomagnetic, sedimentary and structural data. Geologica Carpathica 45, 83-96.

KRÁL', J. 1977. Fission track ages of apatites from some granitoid rocks in West Carpathians. Geologický Zbornik Geologica Carpathica 28, 269-76.

KRÁL, M. 1994. Geothermal characteristics of the Prešov basin and adjacent areas. In Geothermal Energy Atlas of Slovak Republic (ed. O. Franko), pp. 1-15. Open File Report Geofond, Bratislava (in Slovak).

KrÁL, M., LisOL, J. \& JANÁČEK, J. 1987. Geothermal Research in Slovakia, Report 1981-1985. Manuscript Geofyzika Brno, 186 pp. (in Slovak).

KRÁL, M. \& VITÁLOŠ, R. 2003. The Prešov Depression Geothermal water appraisal of its ability for utilization in energetic purposes in northern part depression, geological study. Open File Report Geofond, Bratislava, 24 pp. (in Slovak).

Krist, E., Korikovsky, S. P., PUtiš, M., JANÁK, M. \& FARYAD, S. W. 1992. Geology and Petrology of Metamorphic Rocks of the Western Carpathian Crystalline Complexes. Bratislava: Comenius University Press, 324 pp.

LEXA, J., KONEČNÝ, V., KALIČIAK, M. \& HoJSTRIČOVÁ, V. 1993. Spacetime distribution of volcanics in the Carpatho-Pannonian region. In Geodynamical Model and Deep Structure of Western Carpathians (eds M. Rakús \& J. Vozár), pp. 57-70. Bratislava: Conferences, Symposia \& Seminars GÚDŠ (in Slovak).

LEXA, J., BEZÁK, V., EleČKO, M., EliÁŠ, M., KONEČNÝ, V., Less, Gy., MANDl, G. W., Mello, J., PÁlenskÝ, P., Pelikán, P., PolÁK, M., POTFAJ, M., RAdOCZ, GY., RYlKo, W., SCHNABEl, G. W., StráNíK, Z., VASS, D., VozÁR, J., ZELENKA, T., BIELY, A., CSÁSZÁr, G., ČtYroký, P., KaliČIaK, M., KohÚt, M., Kovacs, S., Mackiv, B., Maglay, J., NemČoK, J., NowOtnÝ, A., Pentelényi, L., RAKús, M. \& VozÁrovÁ, A. 2000. Geological map of Western Carpathians and Adjacent Areas 1: 500,000. Issued by Ministry of the Environment of Slovak Republic Geological Survey of Slovak Republic, Bratislava.

MAdArÁs, J., Hók, J., Siman, P., BezÁK, V., Ledru, P. \& LEXA, O. 1996. Extension tectonics and exhumation of crystalline basement of the Veporicum unit (Central Western Carpathians). Slovak Geological Magazine 34, 179-83.
MAHEL', M. 1986. Geological Structure of the Czechoslovak Carpathians. Paleoalpine units. Bratislava: Veda, 496 pp.

MCDOUgall, I. \& HARRISON, T. M. 1988. Geochronology and Thermochronology by the ${ }^{40} \mathrm{Ar}{ }^{39} \mathrm{Ar}$ Method. New York: Oxford University Press, $212 \mathrm{pp}$.

MÉRES, Š., IVAN, P. \& HovORKA, D. 2000. Garnet-pyroxene metabasite and antigorite serpentinites- evidence of leptino-amphibolite complex in the Branisko Mts. (Tatric unit, central eastern Carpathians). Mineralia Slovaca 32, 479-86.

MOŘKOVSKÝ, M. \& LUKÁČOVÁ, R. 1986. Tectonogenesis of the SE part of the East Slovakian Basin. Mineralia Slovaca 18, 421-33 (in Czech).

MoŘKOVskÝ, M. \& LUKÁČOVÁ, R. 1991. The Geological Structure of the Eastern Margin of the Pannonian Basin in East Slovakia. Luhačovice: Perspektívy naftového priemyslu, 12 pp. (in Czech).

NEMČOK, M. 1993. Transition from convergence to escape: field evidence from the West Carpathians. Tectonophysics 217, 117-42.

PÉCSKAY, Z., LEXA, J., SZAKÁCS, A., SEghedI, J., BALOGH, K., KoneČnÝ, V., Zelenka, T., Kovacs, M., PÓKA, T., FÜlÖP, A., MÁRTON, E., PANAiotu, C. \& CVetKović, V. 2006. Geochronology of Neogene magmatism in the Carpathian arc and intra-Carpathian area. Geologica Carpathica 57, 511-30.

PlašIIENKA, D. 2003. Development of basement-involved fold and thrust structures exemplified by the TatricFatric-Veporic nappe system of the Western Carpathians (Slovakia). Geodinamica Acta 16, 21-38.

PlAŠIENKA，D. 1997. Cretaceous tectonochronology of the Central Western Carpathians (Slovakia). Geologica Carpathica 48, 99-111.

PlašIIENKA, D. 2006. Princípy regionalizácie geologickej stavby Malých Karpát a Považského Inovca. In Nové metódy a výsledky v geológii Západných Karpát (eds M. Kováč \& K. Dubíková), pp. 51-6. Zborník 2006.

PlašienKa, D., Grecula, P., PUTIŠ, M., KováČ, M. \& HovORKA, D. 1997. Evolution and structure of the Western Carpathians: an overview. In Geological Evolution of the Western Carpathians (eds P. Grecula, D. Hovorka \& M. Putiš), pp. 1-24. Mineralia Slovaca Monograph, Bratislava.

Polák, M., Jacko, S., VozÁrová, A., VozÁr, J., Gross, P., HARČÁR, J., SASVÁRI, T., ZACHAROV, M., BALÁŽ, B., LišČÁK, P., MALÍK, P., ZAKOVIČ, M., KAROLI, S. \& KALIČIAK, M. 1997. Explanations to Geological Map of the Branisko and Cierna Hora, 1:50 000. Bratislava: Dionýz Stúr Publishing House, 201 pp. (in Slovak with English summary).

Putiš, M., Frank, W., PlašIEnKa, D., Siman, P., SulÁK, M. \& BIROŇ, A. 2009. Progradation of the Alpidic Central Western Carpathians orogenic wedge related to two subductions: constrained by ${ }^{40} \mathrm{Ar} /{ }^{39} \mathrm{Ar}$ ages of white micas. Geodinamica Acta 22, 55-80.

Ratschbacher, L., Frisch, W., LinZer, H.-G. \& MERle, O. 1991a. Lateral extrusion in the eastern Alps, 2, Structural analysis. Tectonics 10, 257-71.

Ratschbacher, L., Merle, O., Davy, P. \& Cobbold, P. 1991b. Lateral extrusion in the Eastern Alps. 1. Boundary conditions and experiments scaled for gravity. Tectonics 10, 245-56.

REINERS, P. W. 2005. Zircon (U-Th)/He thermochronometry. In Low-Temperature Thermochronology: Techniques, Interpretations, and Applications (eds P. W. Reiners \& T. A. Ehlers), pp. 151-76. Reviews in Mineralogy and Geochemistry vol. 58. 
Reiners, P. W., Spell, T. L., Nicolescu, S. \& Zanetti, K. A. 2004. Zircon (U-Th)/He thermochronometry: He diffusion and comparisons with ${ }^{40} \mathrm{Ar} /{ }^{39} \mathrm{Ar}$ dating. Geochimica et Cosmochimica Acta 68, 1857-87.

REPČOK, I., KALIČIAK, M. \& BACSÓ, Z. 1988. Age of some volcanic rocks of Eastern Slovakia based on the method of Uranium fission tracks. Západné Karpaty, Séria Mineralógia, Petrografia, Geochémia, Metalogenéza 11, 75-88 (in Slovak).

RÖSING, F. 1947. Die geologische Verhältnisse des BraniskoGebirges und Čierna hora (Karpaten). Zeitschrift der Deutchen Geologischen Gesselschaft 99, 8-39.

Royden, L. H., Horváth, F. \& BurChFiel, B. C. 1982. Transform faulting, extension, and subduction in the Carpathian Pannonian region. Geological Society of America Bulletin 93, 717-25.

Royden, L. H., HorvÁth, F., NAGymarosy, A. \& StegenA, L. 1983. Evolution of the Pannonian basin system: 2 . Subsidence and thermal history. Tectonics 2, 91-137.

RUDINEC, R. 1978. Paleogeographical, lithofacial and tectonic development of the Neogene in eastern Slovakia and its relation to volcanism and deep tectonic. Geologický Zborník - Geologica Carpathica 29, 22540.

RUDINEC, R. 1989. New view onto the development of the Transcarpathian depression during the Neogene. Mineralia Slovaca 21, 27-42.

SACHSENHOFER, R. F. 1994. Petroleum generation and migration in the Styrian Basin (Pannonian Basin system, Austria): an integrated organic geochemical and numeric modelling study. Marine and Petroleum Geology 11, 684-701.

Sachsenhofer, R. F., Dunkl, I., Hasenhüttl, CH. \& JELEN, B. 1998. Miocene thermal history of the southwestern margin of the Styrian Basin: vitrinite reflectance and fission-track data from the Pohorje/Kozjak area (Slovenia). Tectonophysics 297, 17-29.

SLÁVIK, J. 1968. Chronology and tectonic background of the Neogene volcanism in Eastern Slovakia. Geologické Práce, Správy 44-45, 199-214.

Slávik, J., Bagdasarjan, G. P., KaličIAK, M., TÖZsÉr, J., ORLICKÝ, O. \& VASS, D. 1976. Radiometric ages of volcanic rocks in the Vihorlat and Slanské mountain ranges. Mineralia Slovaca 8, 319-34 (in Russian with English summary).

SPERNER, B., RATSCHBACHER, L. \& NEMČOK, M. 2002. Interplay between subduction retreat and lateral extrusion: tectonics of the Western Carpathians. Tectonics 21, 124

SOTÁK, J. 1998. Sequence stratigraphy approach to the Central Carpathian Paleogene (Eastern Slovakia): eustasy and tectonics as controls of deep-sea fan deposition. Slovak Geological Magazine 4, 185-90.
StruZIK, A., ZATtin, M. \& AnCZKIEWICZ, R. 2002. Timing of uplift and exhumation of the Polish Western Carpathians. Geotemas 4, 151-4.

Szabó, Cs., HARANGI, S. \& CsONTOS, L. 1992. Review of Neogene and Quaternary volcanism of the Carpathian Pannonian Region. Tectonophysics 208, 243-56.

TARI, G., DövÉNYI, P., DUNKL, I., HorvÁTH, F., LENKEY, L., Stefanescu, M., Szafián, P. \& Tóth, T. 1999. Lithospheric structure of the Pannonian basin derived from seismic, gravity and geothermal data. In The Mediterranean Basins: Tertiary extension within the Alpine Orogen (eds B. Durand, L. Jolivet, F. Horváth \& M. Séranne), pp. 215-50. Geological Society of London, Special Publication no. 156.

TARI, G., HorvÁth, F. \& RuMPLer, J. 1992. Styles of extension in the Pannonian Basin. Tectonophysics 208, 203-19.

VASS, D. \& ČVERČKO, J. 1985. Neogene lithostratigraphic units in the East Slovakian Lowlands. Geologické Práce, Správy 82, 111-26 (in Slovak).

VAss, D., KoneČnÝ, V. \& ŠEFARA, J. 1979. Geology of Ipel'ská Kotlina Depression and Krupinská Planina Mts. Bratislava: Manuscript GÚDŠ, 227 pp. (in Slovak with English abstract).

Vass, D., Tözsér, J., Bagdasarjan, G. P., Kaličiak, M., ORLICKÝ, O. \& ĎURICA, D. 1978. Chronology of volcanic activity in Eastern Slovakia in the light of isotopic and paleomagnetic studies. Geologické Práce, Správy 71, 77-88 (in Slovak with English summary).

VozÁrovÁ, A. \& VozÁR, J. 1986. Correlation of Tectonic Units in the Branisko Mts. Based on the Knowledge of Crystalline Complex and Upper Paleozoic Rocks. Bratislava: Report of GÚDŠ, 26 pp.

VozÁrovÁ, A. \& VozÁr, J. 1988. Late Paleozoic in the Western Carpathians. Bratislava: Manuscript GÚDŠ, $234 \mathrm{pp}$.

VOZÁROVÁ, A. 1993. Pressure-temperature conditions of metamorphism in the northern part of the Branisko crystalline complex. Geologica Carpathica 44, 219-32.

WAGNeR, G. A. \& VAN DEN HAUTE, P. 1992. Fission-Track Dating. Stuttgart: Enke Verlag, 285 pp.

WOLF, R. A., FARLEY, K. A. \& KASS, D. M. 1998. Modeling of the temperature sensitivity of the apatite $(\mathrm{U}-\mathrm{Th}) / \mathrm{He}$ thermochronometer. Chemical Geology 148, 105-14.

WORTEL, M. J. R. \& SPAKMAN, W. 2000. Subduction and slab detachment in the Mediterranean-Carpathian region. Science 290, 1910-17.

ZLÍNSKA, A. 1992. Zur biostratigraphischen Gliederung des Neogens des Ostslowakischen Beckens. Geologické Práce, Správy 96, 51-7.

ŽEC, B. \& ĎURKOVIČOVÁ, J. 1993. Chronostratigraphy of selected volcanic formations in the southern part of Slanské vrchy Mts. Mineralia Slovaca 25, 109-16. 